\title{
Records of brown plumage aberration in the Common Buzzard Buteo buteo
}

\author{
Fynd av brun dräktavvikelse hos ormvråk Buteo buteo
}

MICHAŁ CIACH, ANNA KWARCIANY \& DARIUSZ ŚWITAŁA

\begin{abstract}
The Common Buzzard Buteo buteo presents high plumage variation, but individuals in aberrant plumage are recorded extremely rarely. In August 2005, near Templewo (western Poland), a dead Common Buzzard with aberrant plumage was found. Another individual with aberrant plumage was observed on 14 August 2011 near Minoga (southern Poland). Both birds were beige in most parts of the body with a retained light brown and orange feather pattern. This is the brown mutation, an exceptionally rare plumage aberration in the Common Buzzard.

Michat Ciach, Department of Zoology and Wildlife Management, Forest Biodiversity Institute, Faculty of Forestry, University of Agriculture, al. 29 Listopada 46, 31-425 Kraków, Poland. Corresponding author's e-mail:michal.ciach@ur.krakow.pl

Anna Kwarciany, ul. Aleksandry 9/38, 30-837 Kraków, Poland

Dariusz Świtała, ul. Łętowskiego 10/7, 40-648 Katowice, Poland
\end{abstract}

Received 12 September 2011, Accepted 28 September 2011, Editor: S. Svensson

The Common Buzzard Buteo buteo, having several morphs, presents high plumage variation (Ulfstrand 1977, Dittrich 1985). Three distinct colour morphs (dark, intermediate, and light), with individuals having predominantly white, brown, or mixed plumage on the underside and underwing, have been distinguished in this species. However, extremely pale-coloured individuals, as well as almost entirely dark brown morphs have been recorded (Lontkowski 1985, Forsman 1999). Yet all of these plumage polymorphisms, as a result of changes in colour intensity - melanism and erythromelanism (Thiollay 1994, Schreiber et al. 2001) - present natural plumage variation in this species.

Along with plumage variation, birds with abnormal coloration are recorded. Plumage aberrations in birds are relatively rare, and they usually attract the observer's attention. However, in most species of Falconiformes, records of abnormal coloration are exceptional. Among unusual records are the melanistic Osprey Pandion haliaetus (Clark 1998), the melanistic Northern Harrier Circus cyaneus (Howell et al. 1992), and the albino Australasian Harrier Circus approximans gouldi (Hedley 1983). Based on this, records of aberrant Common Buzzards are interesting.
After mid-August 2005, on the road near Templewo $\left(52^{\circ} 26^{\prime} \mathrm{N}, 15^{\circ} 22^{\prime} \mathrm{E}\right.$, western Poland), a dead Common Buzzard with untypical coloration was found. That bird was a victim of collision with a car. All plumage was clearly beige (Figure 1). The head was all light beige. Underparts were twotoned: a beige breast, with a slightly lighter Ushaped breast band, changing into somewhat darker rusty flanks and thighs. The undertail had almost invisible narrow bars, whereas the tail on the upper side had a slightly more visible feather pattern. The tail, upper tail coverts, rump, and plumage of the tibia had a tinge of carrot orange. The outer primaries (P8-P10) had light brown tips. The rest of the primaries and secondaries had bars with a light coffee colour. The upper wing coverts with a slightly ochre shade differed from the underwing coverts, which were darker and had a bigger amount of carrot orange tinge. As a result of that coloration, the bird appeared more copper from below. Individual mantle feathers and underwing coverts had a visible darker feather pattern with different shades of orange. Bare parts were normally coloured - yellow legs and a black beak with a yellow cere.

On 14 August 2011, in the mosaic of fields and abandoned grounds near Minoga $\left(50^{\circ} 15^{\prime} \mathrm{N}\right.$, 


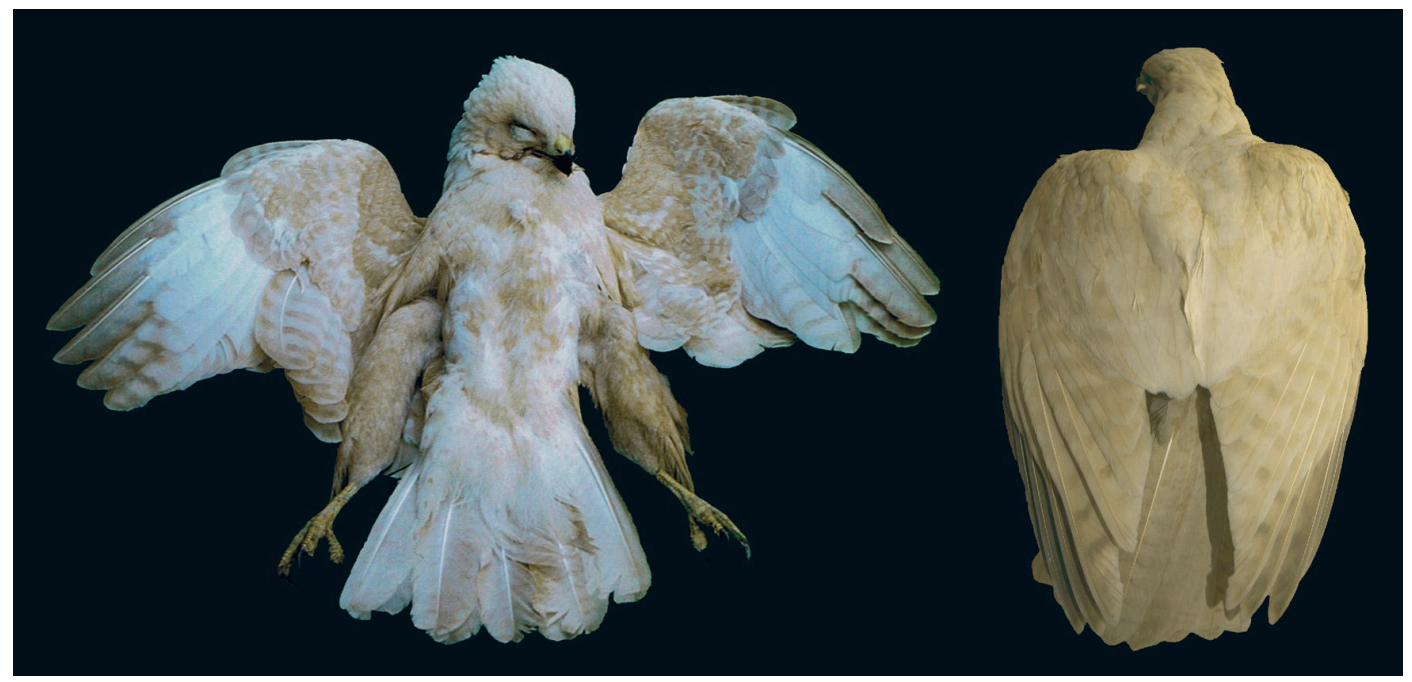

Figure 1. Common Buzzard Buteo buteo with the brown mutation at Templewo, western Poland, August 2005. Ormvråk av den bruna mutationen vid Templewo i västra Polen, augusti 2005.

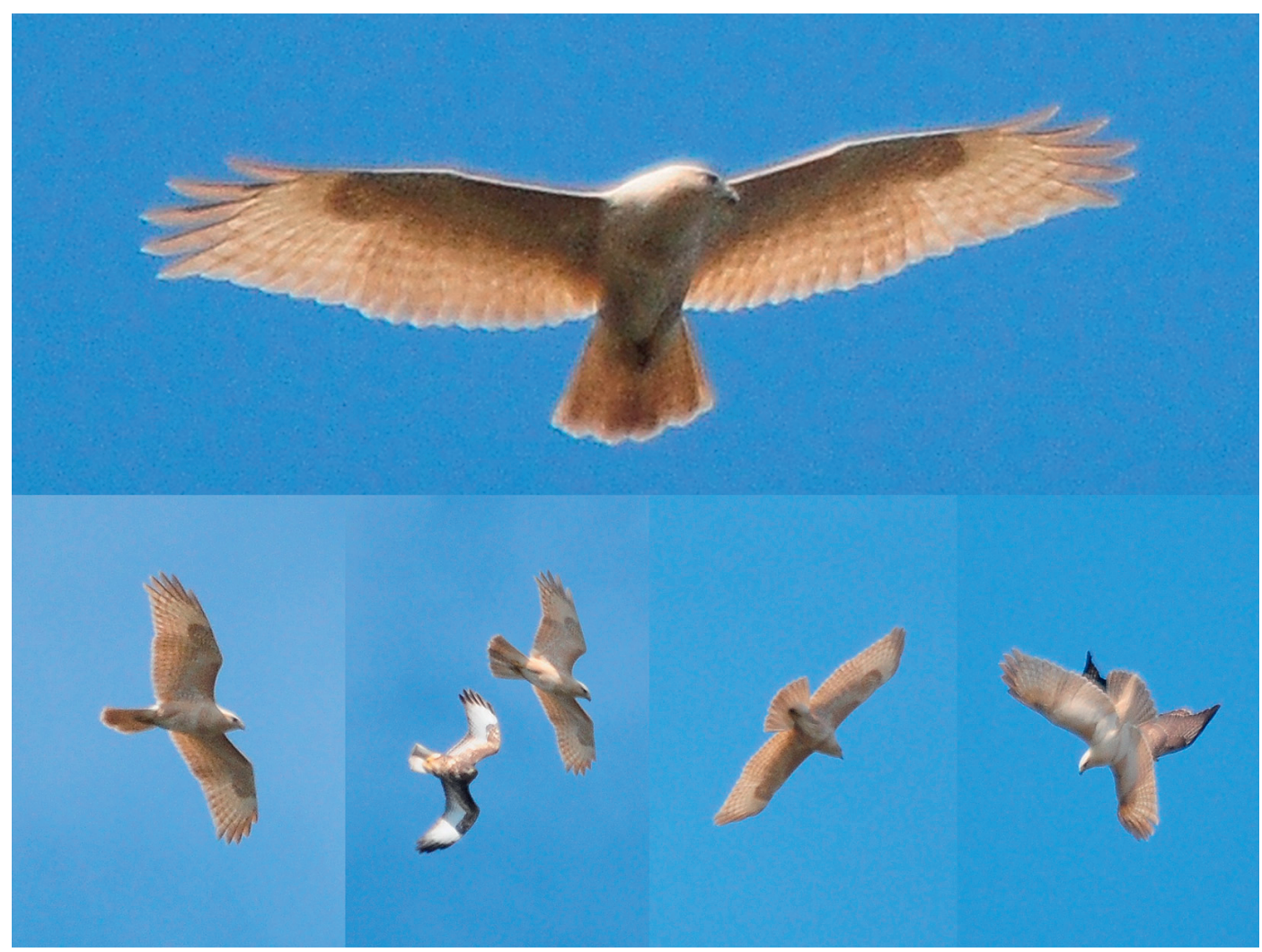

Figure 2. Common Buzzard Buteo buteo with the brown mutation at Minoga, southern Poland, August 2011. Ormvråk av den bruna mutationen vid Minoga i södra Polen, augusti 2011. 
$19^{\circ} 54^{\prime} \mathrm{E}$, southern Poland), another Common Buzzard with untypical coloration was recorded. All plumage was clearly beige (Figure 2). The pattern and coloration of plumage was very similar to that in the first record. The head was all light beige. Underparts were two-toned: a beige breast, with a distinctly lighter U-shaped breast band, changing into somewhat darker rusty flanks and thighs. All primaries and secondaries had a clear feather pattern with visible barring. The upper wing coverts were rather uniform-light beige with a slightly darker trailing edge. The underwing coverts, which were darker than the upper wing, had a visible dark feather pattern and were coloured with a more carrot orange tinge. As a result of the coloration, the bird appeared darker from below. Bare parts were normally coloured - yellow legs and a black beak with a yellow cere. Pale tips to remiges and rectrices indicate fresh juvenile plumage. The observed bird soared with three Common Buzzards in typical plumage and an immature Golden Eagle Aquila chrysaetos. After several minutes of observation, chased by the other Common Buzzards, the aberrant bird flew away.

The described birds had features of brown aberration, which is defined as a qualitative reduction of eumelanin (van Grouw 2006). In this mutation, the amount of pigment remains unchanged, but the appearance of the eumelanin is changed. As a result of an inherited incomplete oxidation of eumelanin, black feathers become dark brown. Feathers with a qualitative reduction of eumelanin are very sensitive to sunlight and bleach quickly and strongly (van Grouw 2006). This may explain the contrast between the underparts and upper parts of both birds. In this mutation, phaeomelanin is unaffected. The information on brown individuals has not been published yet. However, three specimens of the Common Buzzard showing brown mutation are preserved in the collections of museums in Germany, Austria, and Great Britain (H. van Grouw, pers. comm.).

Similar in appearance to brown aberration is dilution. This mutation is defined as a quantitative reduction of melanins. Clark (1999) reported that two dilute-plumage birds are preserved in collections of museums in England and Italy. This aberration has been described in other species of the Buteo genus: in the Roadside Hawk Buteo magnirostris (Aguilar-Rodríguez 1993), the Swainson's Hawk Buteo swainsoni, and the Red-tailed Hawk Buteo jamaicensis (Clark \& Wheeler 2001). Moreover, in the Common Buzzard, albinism and leucism have been recorded so far (Sage 1962, Bělka 2003). As it is shown in this note, in the Common Buzzard, not only the plumage coloration varies extensively, but plumage aberrations also influence individual variation.

\section{Acknowledgements}

Marta Świtała has participated in the observation near Minoga. We are grateful to Hein van Grouw and Bill Clark for constructive comments on earlier drafts of this paper.

\section{References}

Aguilar-Rodríguez, S. H. 1993. First record of dilute plumage in Roadside Hawk (Buteo magnirostris). J. Raptor Res. 27: 49.

Bělka, T. 2003. Leucismus u káně lesní? Panurus 13: 117119.

Clark, W. S. 1998. First North American record of a melanistic osprey. Wilson Bull. 110: 289-290.

Clark, W.S. 1999. A field guide to the raptors of Europe, the Middle East, and North Africa. Oxford University Press, Oxford.

Clark, W.S. \& Wheeler, B.K. 2001. A field guide to hawks of North America. 2. Houghton Mifflin, Boston.

Dittrich, W. 1985. Plumage variations in the buzzard (Buteo buteo) in Northern Bavaria. J. Ornithol. 126: 93-97.

Forsman, D. 1999. The raptors of Europe and the Middle East: A handbook of field identification. T. \& A.D. Poyser, London.

Hedley, L.A. 1983. An example of albinism in the Australasian Harrier Circus approximans gouldi. Notornis 30: 23-28.

Howell, S.N.G., Webb, S., Sibley, D.A. \& Prairie, L. J. 1992. First record of a melanistic northern harrier in North America. Western Birds 23: 79-80.

Lontkowski, J. 1985. Rozpoznawanie różnych form barwnych myszołowów (Buteo spp.), trzmielojada (Pernis apivorus), orzełka włochatego (Hieraaetus pennatus) i krótkoszpona (Circaetus gallicus). Not. Orn. 26: 33-60. (in Polish)

Sage, B.L. 1962. Albinism and melanism in birds. Brit. Birds 55: 201-225.

Schreiber, A., Stubbe, A. \& Stubbe, M. 2001. Common Buzzard (Buteo buteo): A raptor with hyperpolymorphic plumage morphs, but low allozyme heterozygosity. J. Ornithol. 142: 34-48.

Thiollay, J.M. 1994. Family Accipitridae (Hawks and Eagles). In: del Hoyo J., Elliot A. \& Sargatal J. (eds): Handbook of the Birds of the World. Vol. 2. New World Vurtures to Guineafowl. Lynx Edicions, Bacelona.

Ulfstrand, S. 1977. Plumage and size variation in Swedish Common Buzzards Buteo buteo L. (Aves, Accipitriformes). Zool. Scripta 6: 69-75.

Van Grouw, H. 2006. Not every white bird is an albino: sense and nonsense about colour aberrations in birds. Dutch Birding 28: 79-89. 


\section{Sammanfattning}

Ormvråken är känd för att ha en fjäderdräkt som varierar kraftigt i färg, från riktigt mörkbrun till nästan vit. Denna stora variation är en normal polymorfism som uppkommer genom stor variation hos de anlag som styr de olika melaninernas uttryck i färg och färgintensitet. Mycket sällsynt förekommer varianter som inte ligger inom detta variationsmönster. Här rapporterar jag två sådana fall.

Under senare delen av augusti 2005 påträffades en trafikdödad ormvråk nära Templewo i västra Polen. Hel dräkten var beige (Figur 1). Hela huvudet var ljust beige. Undersidan var tvåtonad: ett beige bröst, med ett något ljusare U-format bröstband, som övergick i något mörkare rostfärgade flanker och lår. Stjärtens undersida hade nästan osynliga smala band, medan ovansidan hade något tydligare mönster. Stjärten, övre stjärttäckarna, övergumpen och fjädrarna på tibian hade en anstrykning av morotsorange. De yttre handpennorna (P8-P10) hade ljusbruna spetsar. Resten av handpennorna och armpennorna lätt kaffefärgade band. De övre vingtäckarna hade en lätt ockraton och skiljde sig från de undre vingräckarna som var mörkare med mer morotsorange anstrykning. Denna färgsättning gav intryck av mera kopparton underifrån. Individuella ryggfjädrar och undre vingtäckare hade synliga mörkare mönster i olika toner av orange.
Obefjädrade kroppsdelar var normalt färgade med gula ben, svart näbb och vaxhud.

Den 14 augusti 2011 fotograferades en ormvråk med otypisk färg nära Minoga i södra Polen (Figur 2). Den liknade mycket den nyss beskrivna. Huvudet var ljusbeige. Undersidan var tvåtonad: beige bröst, med ett tydligt ljusare U-format bröstband, som övergick i något mörkare rostfärgade flanker och lår. Alla handpennor och armpennor var tydligt bandade. Övre vintäckarna var ganska enfärgat ljusbeige med något mörkare bakkanter. Undre vingtäckarna, som var mörkare än de övre, hade synliga mörka teckningar och var mera morotsorange. Obefjädrade kroppsdelar var normalt färgade. Denna individ kretsade tillsammans med tre normalfärgade ormvråkar och en kungsörn.

Jag har tolkat den beskrivna variationen som den bruna mutation som van Grouw (2006) nämner som orsakad av en kvalitativ reduktion av eumelanin, då mängden pigment är oförändrat men dess färguttryck förändrats. En färgvariant som kallas utspädning, och som är mycket lik den bruna mutationen, finns också och skall bero på en kvantitativ reduktion av melaninerna. Den bruna mutationen har inte tidigare publicerats, men exemplar finns på muséer i Tyskland, Österrike och Storbritannien. Även exempel på varianten utspädning har rapporterats från muséer i England och Italien. 